Canadian University Music Review

Canadian University Music Review

Revue de musique des universités canadiennes

\title{
Two Instrumental Arrangements from Early Sixteenth-Century Bohemia
}

\section{Edward Kovarik}

Numéro 15, 1995

URI : https://id.erudit.org/iderudit/1014394ar

DOI : https://doi.org/10.7202/1014394ar

Aller au sommaire du numéro

\section{Éditeur(s)}

Canadian University Music Society / Société de musique des universités canadiennes

\section{ISSN}

0710-0353 (imprimé)

2291-2436 (numérique)

Découvrir la revue

\section{Citer cet article}

Kovarik, E. (1995). Two Instrumental Arrangements from Early Sixteenth-Century Bohemia. Canadian University Music Review / Revue de musique des universités canadiennes, (15), 91-107.

https://doi.org/10.7202/1014394ar

\section{Résumé de l'article}

The Specialnik manuscript (HradKM II.A.7), from early sixteenth-century Bohemia, includes two well-known works with unique supplementary voices. One work, the final Agnus of Brumel's Missa Ut re mi fa sol la, includes an added bassus which deepens the composite range and animates the original without seriously disrupting it. An analysis of this movement shows why it was popular as an independent instrumental piece: it is clearly structured as statement and heightened reprise. The second work, Bedingham's

"Fortune/Gentil madonna" contains a similar kind of bassus (as a substitute for the original contratenor) and also a triplum which exhibits characteristics of an idiomatic instrumental style. The Spec arrangement prompts a re-examination of the other sources and a demonstration that Bedingham's song originally called for a change from triple to duple mensuration in its B section.
All Rights Reserved @ Canadian University Music Society / Société de musique des universités canadiennes, 1995
Ce document est protégé par la loi sur le droit d'auteur. L’utilisation des services d'Érudit (y compris la reproduction) est assujettie à sa politique d'utilisation que vous pouvez consulter en ligne.

https://apropos.erudit.org/fr/usagers/politique-dutilisation/ 


\section{TWO INSTRUMENTAL ARRANGEMENTS FROM EARLY SIXTEENTH-CENTURY BOHEMIA}

\section{Edward Kovarik}

Some years ago Benvenuto Disertori published an arrangement of the anonymous mid fifteenth-century rondeau J'ay pris amours in which the original discantus and tenor voices are supplemented by a unique third voice, faster moving than the other parts and different from them in melodic character. ${ }^{1}$ The part is unlabelled, but since it remains below the tenor throughout, it is in effect a bassus rather than a contratenor. Disertori noted that the stereotyped dotted rhythms and repetitive scalar passages found in this part are not at all unusual in music from the turn of the sixteenth century (he prints an example from Josquin's Missa Hercules Dux Ferrariae), but he also pointed out that they are remarkably similar to the diminution formulas later systematized by Diego Ortiz in Tratado de glosas sobre clausulas y otros generos de puntos en la musica de violones (Rome, 1553). Impressed by the similarities, Disertori referred to the added part as a "basso passagiato" and concluded that it must have been intended for a viol. Adopting Ortiz's terminology, he referred to the entire piece as a "primitive recercar on J'ay pris amours."

In the modern view, Disertori's ricercar can be seen as just one more example of the common late fifteenth-century practice of creating alternative, often "modernized" versions of popular chanson-style pieces. ${ }^{2}$ Many of these arrangements resemble Disertori's ricercar in adding one or two newly-composed voices to the original discantus/tenor duet; some, however, employ other procedures. At one extreme, only a single voice - or an even smaller fragment - is taken over and used as the basis of an essentially new composition. At the other extreme, the entire polyphonic complex is retained, but with one or more supplementary

1 "Il manoscritto 1947-4 di Trento e la canzone 'J'ay pris amours,"' Rivista Musicale Italiana 48 (1946): 1-29.

2 Numerous examples are cited in Helen Hewitt and Isabel Pope, eds., Harmonice Musices Odhecaton A (Cambridge, Mass: The Mediaeval Academy of America, 1942) and in Hewitt's Canti $B$ (Chicago: University of Chicago Press, 1967). For an extensive study of one model and its arrangements, see Hewitt's "Fors seulement and the Cantus Firmus Technique of the Fifteenth Century," Essays in Musicology in Honor of Dragan Plamenac, ed. G. Reese and R. Snow (Pittsburgh: University of Pittsburgh Press, 1969), 91-126. 
voices added to it. A well-known example of this latter type is Walter Frye's Ave Regina: three of its sources preserve supplementary high parts (distinct from one another) that may be used in conjunction with the original three voices. ${ }^{3}$ Another example is the textless piece Nec mihi nec tibi, discussed briefly by Frank D'Accone and at greater length by Allan Atlas. ${ }^{4}$ Attributed variously to Obrecht and to one Virgilius, whom D'Accone has located at the Cathedral of Florence in the first decade of the sixteenth century, Nec mihi evidently originated as a two-voice chanson; however, four of its six sources preserve a rather clumsily written third part that functions as a bassus. ${ }^{5}$

As it happens, one of the manuscripts that contains supplementary voices for both Nec mihi and Ave Regina contains two other works with added bassus parts similar to Disertori's "basso passagiato." The source is the Specialnik manuscript (Ms. II.A.7) of the Krajske Muzeum Vychodnich Cech (Regional Museum of Eastern Bohemia) at Hradec Kralove (Königgrätz). ${ }^{6}$ The Specialnik manuscript (usually abbreviated Spec) was studied by Dobroslav Orel in the early decades of this century. ${ }^{7}$ Later it was mentioned in passing by Dragan Plamenac; 8 more recently, it has been inventoried by the Czech scholar Jaromir Cerny ${ }^{9}$ and included in the census of renaissance manuscripts published by the University of Illinois. ${ }^{10}$

3 All of the supplementary voices are included in one composite transcription in Sylvia W. Kenney (ed.), Walter Frye: Collected Works, Corpus Mensurabilis Musicae 19 (American Institute of Musicology, 1960): 10-12.

4 Frank A. D'Accone, "Some Neglected Composers in the Florentine Chapels, ca. 1475-1525," Viator 1 (1970): 281-284; Allan Atlas, The Cappella Giulia Chansonnier (C.G. XIII.27): (Brooklyn: Institute of Medieval Music, 1975), 1: 131-33, with a list of sources.

5 Atlas has suggested that Obrecht wrote the two-voice original and that Virgilius was responsible only for the added third part. Each attribution occurs in just one of the sources of the three-voice version; elsewhere the piece is anonymous.

6 I wish to thank Dr. Milan Koubek, Director of the Krajske Muzeum, for permission to edit these extracts from the Specialnik manuscript.

7 A thematic index is included in Orel's dissertation, "Der Mensuralkodex 'Specialnik:' Ein Beitrag zur Geschichte der Mensuralmusik und Notenschrift in Böhmen bis 1540," (University of Vienna, 1914); a textual index with extensive annotations and some thematics appears in Orel's Pocatky Umeleho Vicehlasu v Cechach [The Origins of Artistic Polyphony in Bohemia], Sbornik Filozofickej Fakulty 1/8 (University of Bratislava, 1922).

8 Dragan Plamenac, "Browsing through a Little-Known Manuscript," Journal of the American Musicological Society 13 (1960): 102.

9 Cerny's textual index (intercalated with the contents of other manuscripts) appears in Soupis Hudebnich Rukopisu Muzea v Hradci Kralove [Inventory of Musical Manuscripts at the Museum in Hradec Kralove], Miscellanea Musicologica 19 (Prague: Charles University, 1966).

10 Census-Catalogue of Manuscript Sources of Polyphonic Music: 1400-1550, 5 vols. (American Institute of Musicology, 1979-1988), 1: 272; 4: 405-6. Citations of sources not otherwise identified follow the abbreviations in this work. 
The two works just mentioned appear in Spec as five-voice pieces: in one, a supplementary bassus is added to an original four-voice structure; in the other, two new voices - bassus and triplum - appear together with a three-voice original. The triplum in particular is a remarkable example of idiomatic instrumental writing around the beginning of the sixteenth century.

The first piece (example 1) is an adaptation of the last section, Agnus III, of Antoine Brumel's Missa Ut re mi fa sol la, perhaps the earliest surviving hexachord mass. ${ }^{11}$ This section, which is the musical climax of Brumel's mass, ${ }^{12}$ exists in a number of sources as an independent instrumental piece - testimony to its compelling musical structure. This was planned by Brumel as a leisurely first statement followed by an intensified reprise. In the first statement (the top four voices of example 1, mm. 1-24), four-voice segments containing the slow moving cantus firmus are interrupted every few bars by duo interludes in faster rhythms; thus the whole first statement proceeds at a fairly low level of intensity. In the reprise the hexachord is stated without interruption, and the faster-moving material (now in three voices) accompanies the cantus firmus rather than alternating with it; the result is a much greater sense of activity.

To some extent, the added voice in Spec disrupts the composer's plan, since it animates the quiet first section and thickens the duos. However, it enriches the climactic second part even more, since it moves more continuously, and at the high point of the cantus firmus (mm. 29-30) it reinforces the simple alternating harmonies of the other accompanying voices. Moreover, the supplementary part effects a substantial gain in sonority: in the recurring G-chords it adds the lower octave, and at cadence points it supplies the 5-1 bass movement that is lacking in the original. At one point it even creates a kind of deceptive cadence ( $\mathrm{mm} .13-$ 14) as preparation for the authentic cadence a bar later, a pleasing effect of which there is no hint in the original.

Apart from the added voice, the Spec version of this piece differs in some respects from the version found in other sources. The note $b$ in the third voice on the second quarter of $\mathrm{m} .17$, for example, in unique in Spec; other sources have $c$ ' here. The $b$ is obviously a change from the original, called forth by the lower fifth in the added part. The same explanation may account for the note $d$ in the fourth voice at the middle of $\mathrm{m} .32$ : all other sources have $\mathrm{f}$ here, but the presence

11 See table 1 for a list of sources; Spec and the Verona manuscript should be added to the sources given in the Collected Edition.

12 The mass systematically explores all seven traditional hexachord positions, starting with the lowest one (on Gamma-Ut) in the Kyrie. The first C-hexachord appears in the Gloria, the first F-hexachord in the Credo, and so on. Thus Agnus III employs the highest hexachord and reasserts $\mathrm{G}$ as key-note. 
Example 1: Brumel, Missa Ut Re Mi Fa Sol La, Agnus III

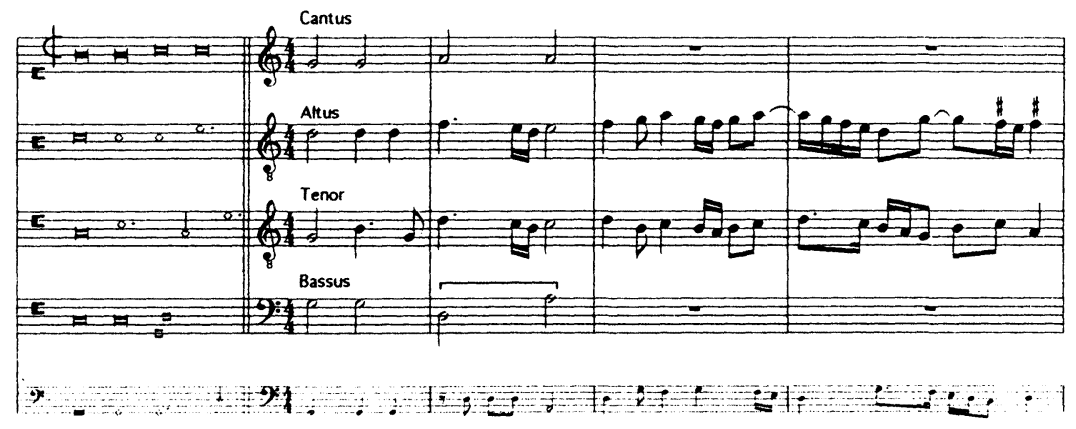

(5)

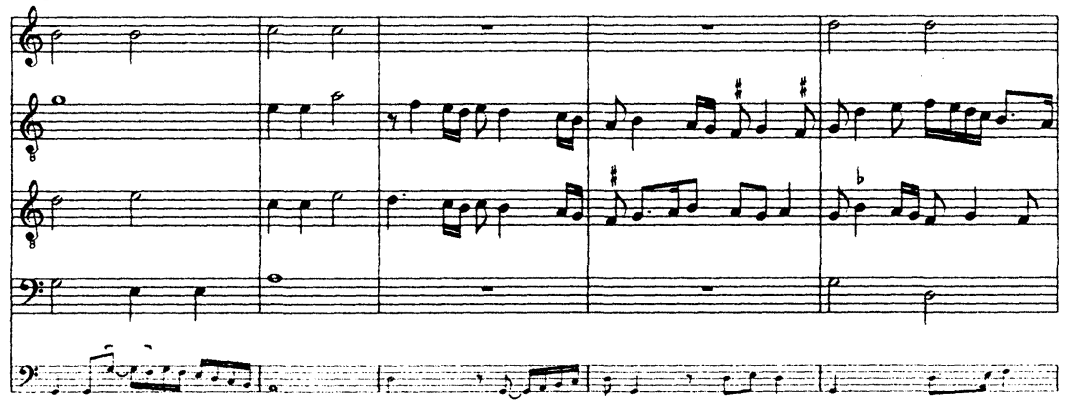

(10)

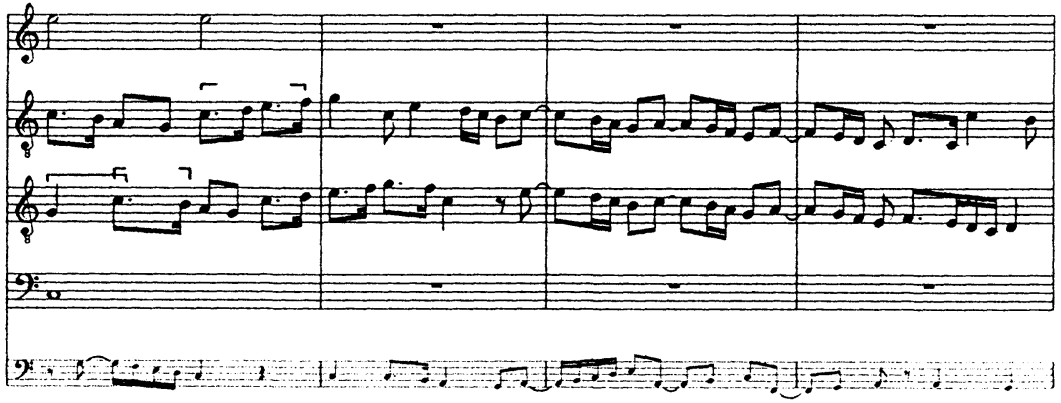


Example 1: (continued)

(15)

(20)

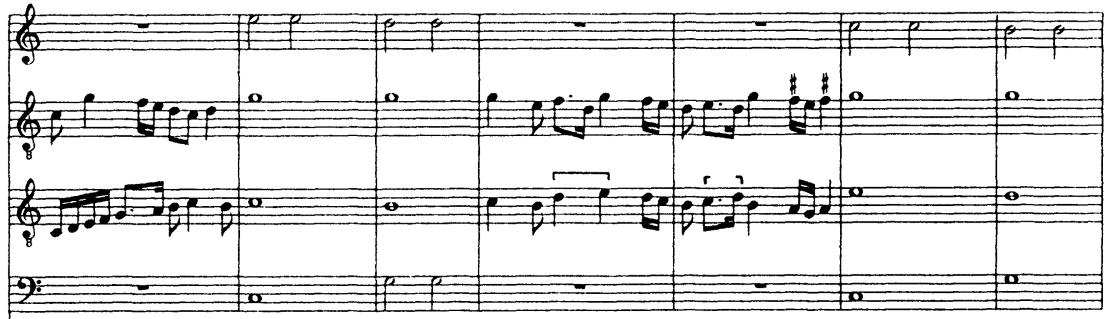

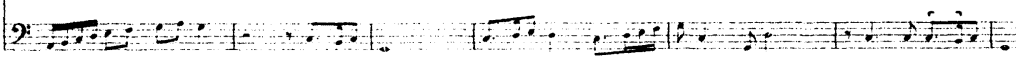

(25)

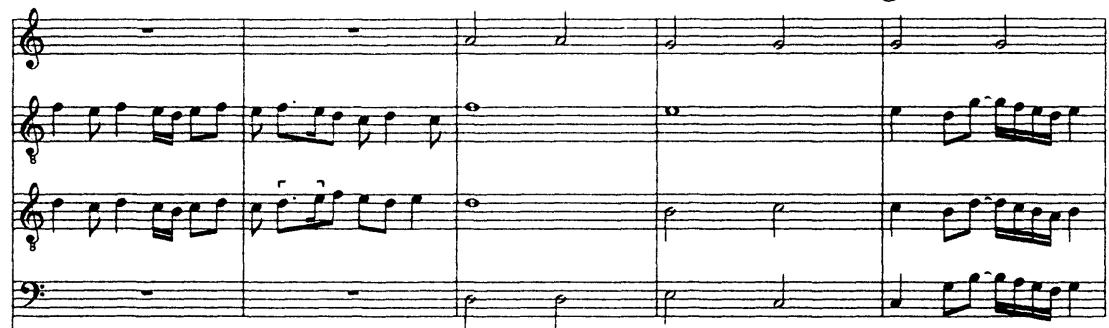

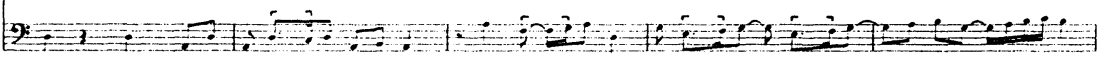

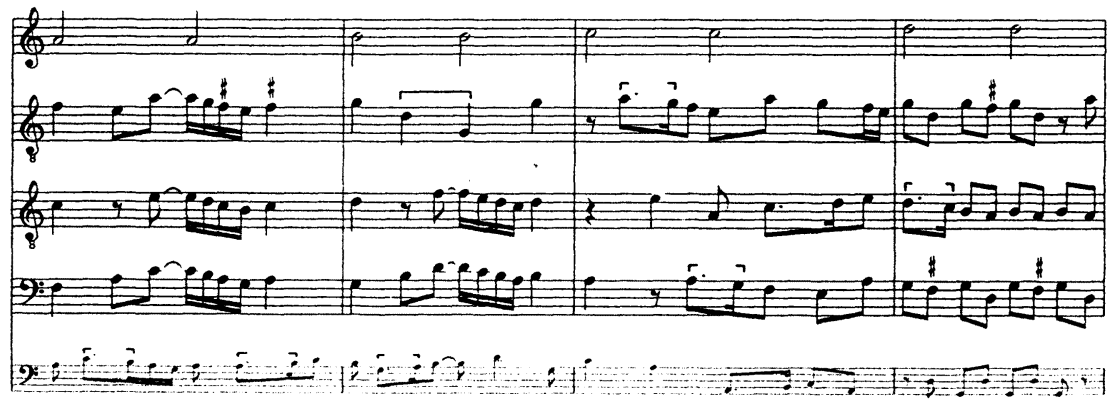


Example 1: (concluded)

(30)

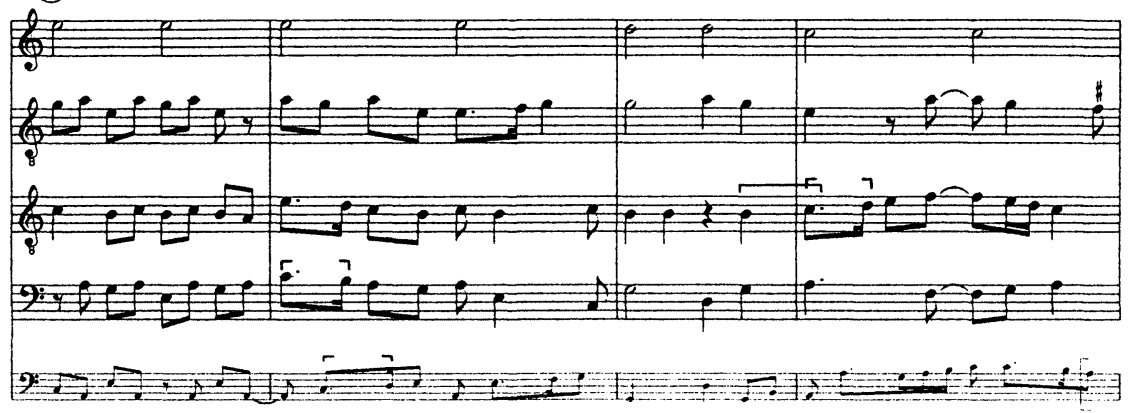

(35)

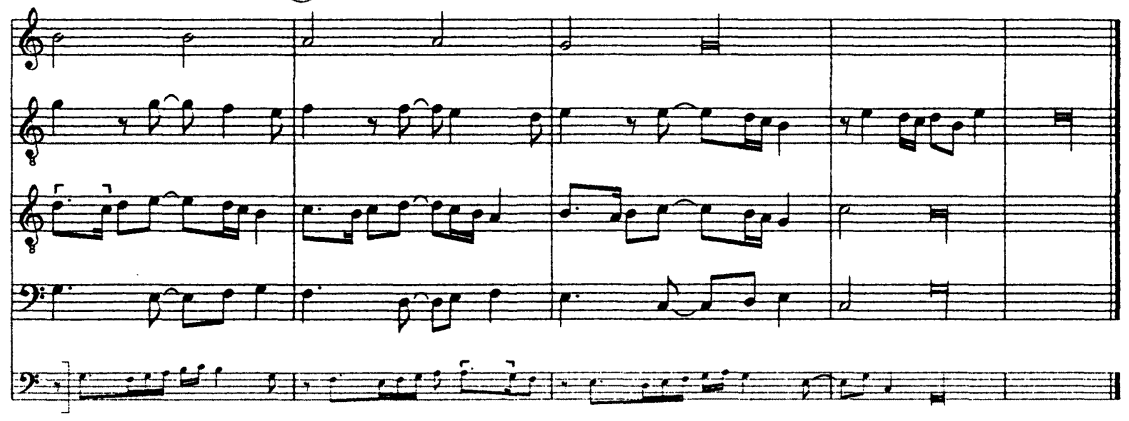

of a new bass note may have prompted the change. Other significant variation in Spec includes the suppression of cadential figuration in the inner voices at $\mathrm{mm}$. 25-26 and 33-35 (present in all other sources) and the division of the cantus firmus into paired breves; other sources have single longas. There are also a few minor corruptions. ${ }^{13}$ All of this shows that the Spec version stands at the end of its own line of transmission and is not closely related to any of the other sources listed in Table 1. Spec thus provides an independent example of the popularity of this climactic final Agnus, and it also preserves a unique adaptation of it.

13 The principal corruptions in Spec occur in the inner voices of Ex. 1 at mm. 11, 28, 30-31. See Hudson's transcription for the usual readings, but note the following misprints there: $\mathrm{m}$. 63, 3rd voice: the note should be e, not $c ; m$. 74-75, I st voice: the missing note is $\mathrm{e}^{\text {", }}$ top note of the cantus firmus (the measure numbers are Hudson's, counting from Agnus I). 
Table 1. Brumel, Missa Ut re mi fa sol la, Agnus III (example 1): Sources

Complete Mass:

Misse Brumel. Venice: O. Petrucci, 1503 (No. 3) RISM A I/1: 430 (B 4643)

Stuttgart. Württembergische Landesbibliothek, Cod. mus. I 47, ff. 114-141. Census 3: 190; 4: 477 (StuttL 47)

Vatican City. Biblioteca apostolica vaticana, Ms. Cappella Sistina 45, ff. 149v-168. RISM B IV/5: 389. Census 4: 48 (VatS 45)

Agnus III only:

Bologna. Civico museo bibliografico musicale, Q 18, ff. 85v-86 “Agnus dei." RISM B IV/5: 45. Census 1: 72; 4: 276. (BolC Q18)

Hradec Kralove, Krajske Muzeum, Ms. II.A.7 (Spec) ff. 234-235 (no text). Census 1: 272; 4: 479 (HradKM 7).

Verona, Biblioteca capitolare, Ms. DCCLVII, ff. 21v-22 (no text). RISM B IV/5: 562. Census 4: 77 (VerBC 757)

Lute arrangements of Agnus III:

Intabolatura de lauto. Libro secondo. [Fr.Spinacino] Venice: O. Petrucci, 1507, ff. 5v6v "Agnus de ut re mi fa sol la" RISM B I/1: 95 (1507/6).

Chicago. Newberry Library, Capirola Lute Book, No. 22: “Agnus dei de brumel.” RISM B VII: 79.

Edition:

Hudson, Barton. Antonii Brumel: Opera Omnia, Corpus Mensurabilis Musicae 5 (American Institute of Musicology, 1969), 1: 41-64.

\section{References}

Census:

University of Illinois Musicological Archives. Census Catalog of Manuscript Sources of Polyphonic Music: 1400-1550, 5 vols. American Institute of Musicology, 19791988.

RISM:

Répertoire international des sources musicales, published by the International Musicological Society and the International Association of Music Libraries, Archives and Documentation Centres.

A I/1 Schlager, K. Einzeldrucke vor 1800. Kassel: Bärenreiter, 1971.

B I/1 Recueils imprimés: XVIe-XVIIe siècles. Munich: Henle, 1960.

B IV/3 Fischer, K. von and M. Lütolf. Handschriften mit mehrstimmiger Musik. Munich: Henle, 1972.

B IV/5 Bridgman, N. Manuscrits de musique polyphonique XVe et XVle siècles: Italie. Munich: Henle, 1991.

B VII Boetticher, W. Handschriftlich überlieferte Lauten- und Gitarrentabulaturen des 15. bis 18. Jahrhunderts. Munich: G. Henle, 1978. 
The second piece in Spec (example 2) is an arrangement of the well-known mid fifteenth-century chanson "Fortune elas / Gentil madonna," which is preserved in nearly a dozen manuscripts and which also exists in a keyboard arrangement and as the model for a four-voice parody mass. ${ }^{14}$ The chanson is attributed to "Jo Bodigham" (Bedingham) in the Schedel Liederbuch but is anonymous elsewhere.

The piece is in two sections, and in most sources (though not in Spec) fermate or signa congruentiae appear near the end of the A section (these are shown in square brackets in example 2). Presumably the signs indicate a pause at this point ("first ending"), followed by a repeat from the beginning and a continuation through to the end of the section ("second ending"). Supporting this interpretation is the fact that the last several bars of the A section (mm. 8-13) are identical with the end of the B section (mm. 38-45); this kind of "musical rhyme" is characteristic of the fourteenth and fifteenth-century ballade, which has exactly this kind of repeated first section.

The double title given to this piece reflects the claims of two different texts. An incipit in French, "Fortune elas," appears in one form or another in all of the German sources and in a few Italian ones; a more-or-less complete Italian text, beginning "Gentil madonna," appears in most of the Italian sources ( $M e l$ has both the French incipit and the Italian text).

This text varies widely from one source to another, and none of the versions fits the music very closely. Several scholars have tackled this problem and come up with differing solutions; ${ }^{15}$ most agree, however, that "Gentil madonna" was a replacement for the original "Fortune" text. It has even been suggested that the French incipit may be a corruption of an English original, such as the text beginning "Fortune alas, alas what have I gylt" which survives in three English text sources. ${ }^{16}$

Unlike the other manuscripts, Spec does not include a textual reference to

14 See table 2 for a list of sources and related works. The chanson is cited in the index of an additional source, BolC Q16, but no longer appears in the body of that manuscript; see Sarah Fuller, "Additional Notes on the 15th-century Chansonnier Bologna Q 16," Musica Disciplina 23 (1969): 85.

15 See Perkins and Garey, The Mellon Chansonnier 2: 379-384; Pope and Kanazawa, The Musical Manuscript Montecassino 871, 621-622. A four-line French text beginning with the words "Fortune hellas" has been discovered by Brigitte Kultzen in an anonymous and musically independent Parisian chanson printed in Attaingnant's Trente et cinque chansons, RISM B I/1, 1528/7). The text is printed in Peter Reidemeister, Die Chanson Handschrift 78.C.28 (Munich: Katzbichler, 1973), 93.

16 Perkins and Garey, The Mellon Chansonnier 2: 377; David Fallows, "Bedyngham," in The New Grove Dictionary of Music and Musicians (London: Macmillan, 1980), 2: 349. 
Example 2: Bedingham, Fortune elas/Gentil Madonna
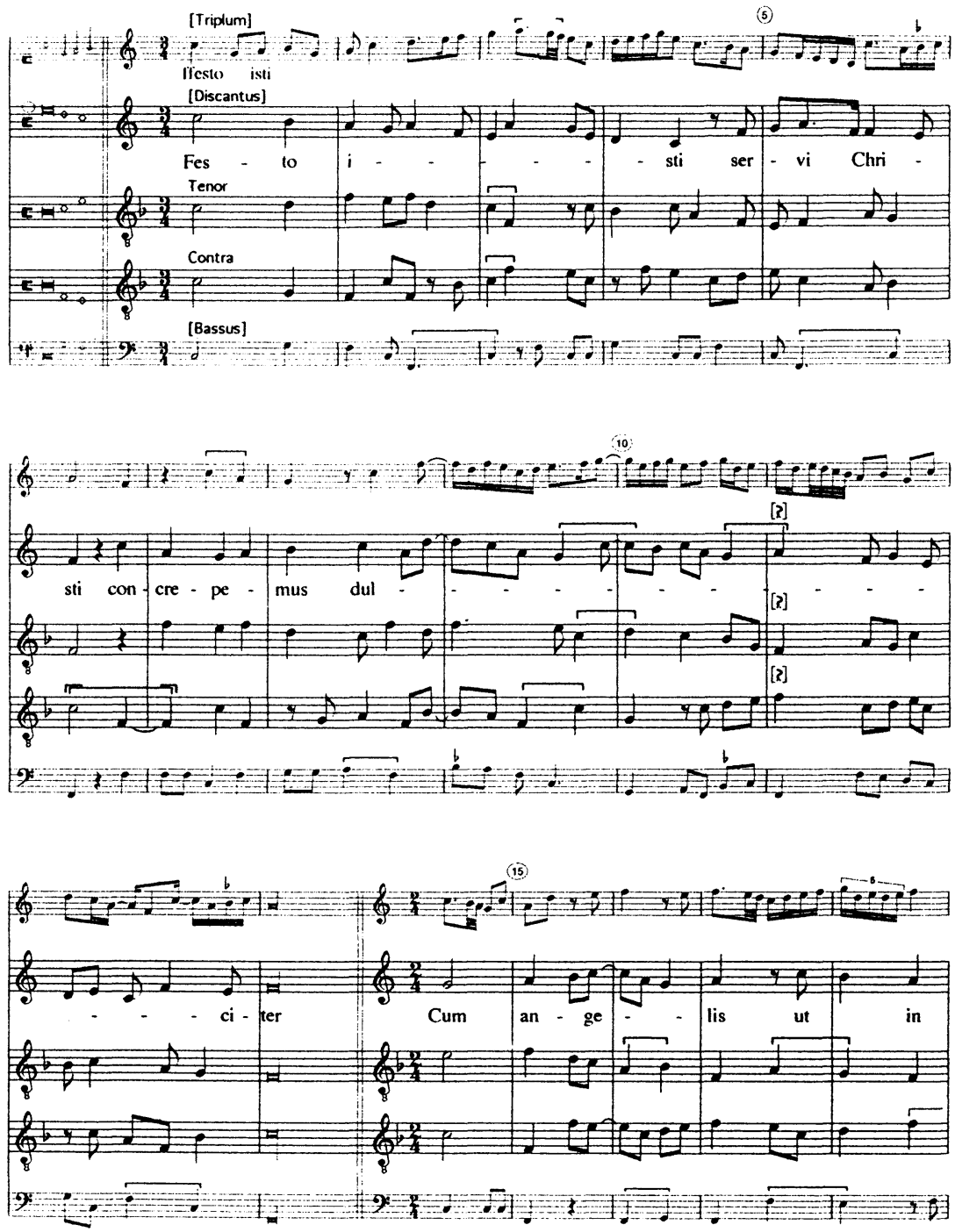
Example 2: (continued)
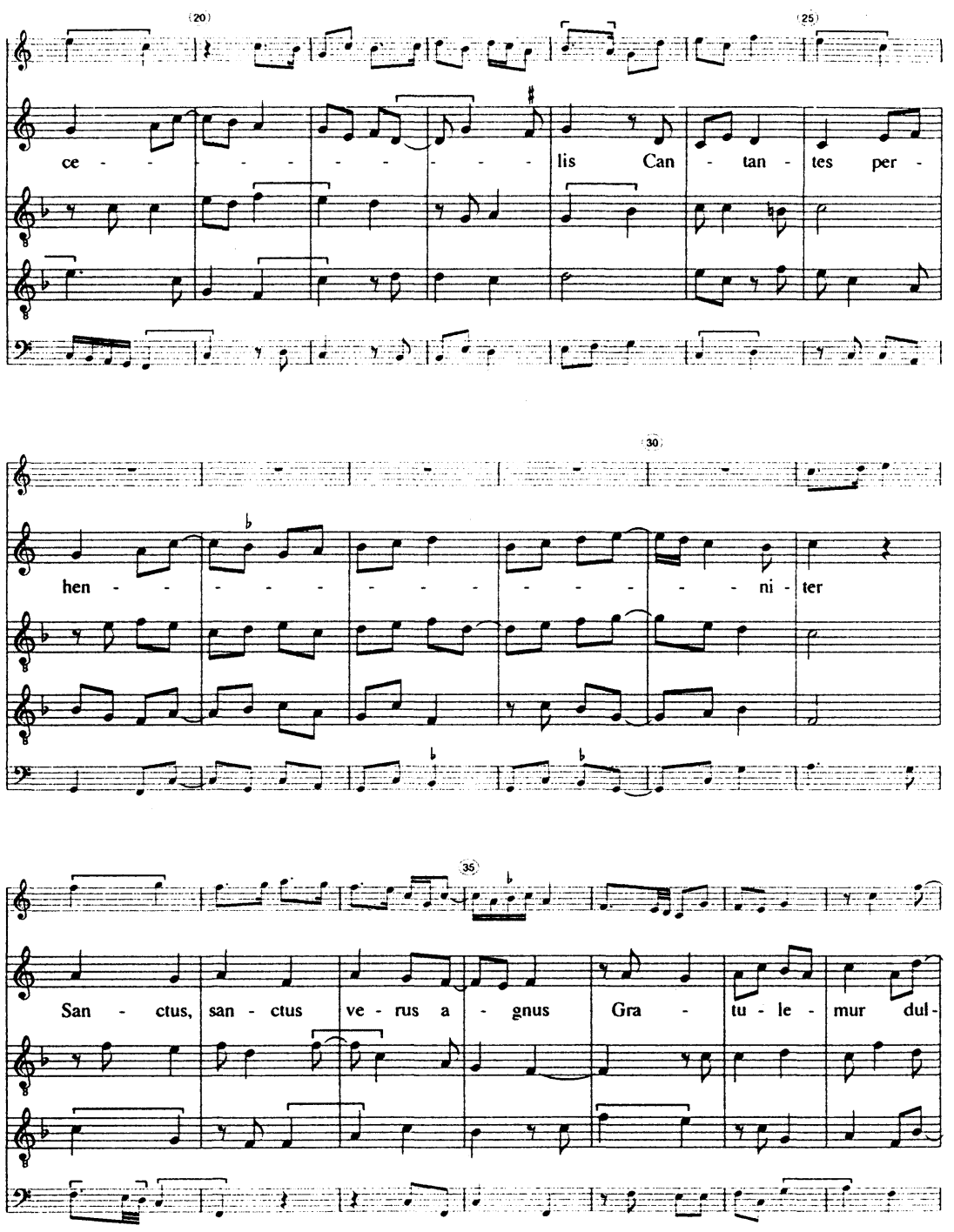
Example 2: (concluded)

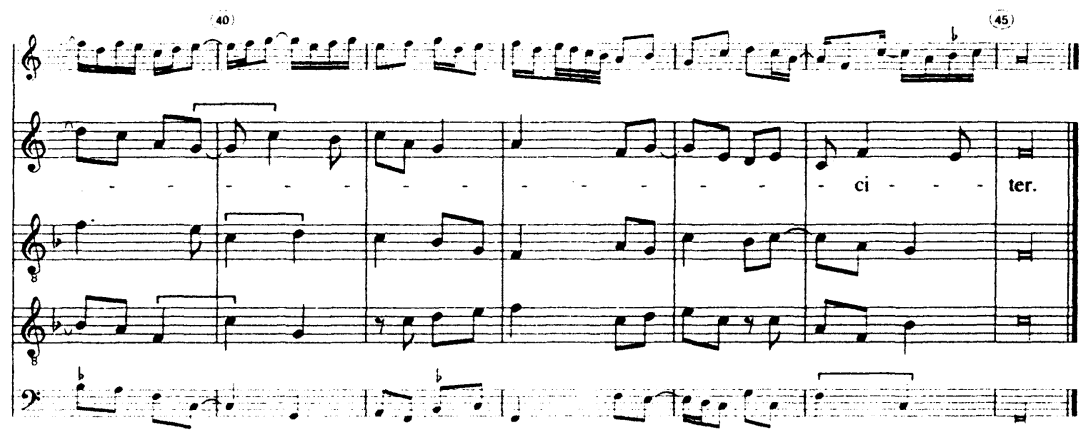

either "Gentil madonna" or "Fortune." Its discantus has only the unique sacred Latin text given below. ${ }^{17}$

A: Festo isti servi Christi

Concrepemus dulciter

B: Cum angelis ut in celis

Cantantes perhenniter

Sanctus, Sanctus, verus Agnus

Gratulemur dulciter.

On the feast of this servant of Christ

Let us concord sweetly

With the angels, so that in heaven,

Singing eternally,

"Holy, holy, true Lamb,"

We may rejoice sweetly.

The assignment of two lines of text to the A section and four lines to $B$ fits the phrase structure of the music quite well. Internal rhymes occur in the oddnumbered lines, and there is a textual resonance (corresponding to the musical rhyme) at the ends of the two sections. No text is supplied for a repeat of the A section, but as mentioned, Spec does not include the signs that would call for such a repeat.

17 Latin contrafacta of secular songs are fairly common in central European sources. A second Latin text for "Gentil madonna" appears in the German manuscript 5023 (see table 2). 
The middle three staves of example 2 reproduce the original three voices of Bedingham's song; the top and bottom staves are the added voices found only in Spec. The original tenor and contratenor are labelled in Spec (as in most of the other sources); the fifth voice is unlabelled on the first opening (p.402) but is one of the two parts called "contratenor" on the second opening (pp. 404-5); to avoid confusion with the original contratenor, I will call this part "bassus." For the top two voices, I have supplied the conventional labels "triplum" and "discantus." 18

The relationship of contratenor and bassus is problematic; most of the time they either double one another or else clash severely (mm. 11, 17-18, 22-23, etc.). Evidently these voices are mutually exclusive, even though there is no rubric to this effect in the manuscript. Thus Spec contains not a single five-voice setting, but rather two alternate versions: the three-voice original and a fourvoice arrangement in which triplum and bassus supplement the original discantus and tenor.

No mensuration signs appear inSpec, but the mensurations can be determined from internal evidence: breve coloration in the contratenor (mm. 6-7) shows that the A section must be in tempus perfectum ( $3 / 4$ time in transcription); a string of five imperfect breve rests (equivalent to ten semibreves) at mm. 26-30 of the triplum shows that the B section must be in tempus imperfectum $(2 / 4$ time in transcription). The first part of this deduction is easily confirmed: most of the concordant versions do indeed display the full circle of tempus perfectum at the beginning. The second part is a different matter: the chanson sources do not as a rule indicate a change of mensuration at the beginning of the $B$ section. Indeed, sporadic examples of breve coloration confirm that some of the scribes thought of the B section as continuing in tempus perfectum.

Nevertheless, there is significant evidence to show that the imperfect rests in Spec are not a scribal abberation. Most important is the pattern of mensurations found in the parody mass of Tr.91. This is based on the tenor of "Gentil madonna," taken over note-for-note, ${ }^{19}$ and as might be expected, the latter part of each movement makes use of the B section of the song; this part of the cantus

18 Some of the clefs in Spec are incorrect. The clef of the discantus appears throughout as c-3 but should be $\mathrm{c}-1$; the clef of the triplum appears as $\mathrm{c}-1$ but should be $\mathrm{g}-2$. The clef of the bassus is given correctly as F-4 on the first opening, but incorrectly as F-4 on the second opening; here it should be F-5. Other emendations in Ex. 2 are as follows. Triplum: the rhythm given in Spec for the third beat of $\mathrm{m} .10$ is $\mathrm{m} \mathrm{sm} \mathrm{sm}$; it has been reversed so as to match the end of $\mathrm{m} .41$; Discantus: the third eighth-note of $m .39$ in Spec reads $s m b^{\prime}, s m$ a'; it has been changed to $m$ a' to match the other sources; Tenor: $\mathrm{m}$. 15, the second and third notes are written a step too low in Spec; $\mathrm{Ct}$ : $\mathrm{m}$. 26, the first note is written a step too high; Bassus: $\mathrm{mm}$. $43-45$, the last five notes are written a third too high.

19 At the beginnings of major sections of the mass the other voices of the song are also quoted. 
firmus is always notated in tempus imperfectum. Moreover, the signature $\mathrm{C}$ does appear in a few of the chanson sources. It occurs at the beginning of the B section in $\mathrm{BerK}$ and in $\mathrm{Pav}$ (tenor voice only); it also appears by mistake at the beginning of the first section in $M C$ (discantus only), where the full circle of tempus perfectum was first written, then crossed out and replaced by a $C$. Thus it is reasonable to conclude that a change to duple mensuration in the $\mathrm{B}$ section was intended by the composer but eventually suppressed in a majority of the sources.

Mensuration changes are unusual in the fifteenth-century song: they do not occur in other ballades with English text such as "Alas is my chief song," "Myn hertis lust," or "So ys emprentid." ${ }^{20}$ However, some precedent can be found in a few of Dufay's French ballades, which begin in C-dot (tempus imperfectum/ prolatio perfecta), change to $\mathrm{O}$ (tempus perfectum) at the $\mathrm{B}$ section and then resume the original mensuration for the refrain. ${ }^{21}$ In English sacred music of this period, as exemplified by the Latin works of Dunstable, ${ }^{22}$ changes from $\mathrm{O}$ to $\mathrm{C}$ are quite common.

In addition to the mensuration shift, Spec preserves several other variant readings which may represent an early version of Bedingham's song. This is not to suggest a direct link with the composer, but merely to point out that Spec is one of the few sources of this work which is independent of the relatively late "Italian tradition," a tradition defined both by the "Gentile madonna" text and by certain rhythmic divisions of long notes associated with the text. ${ }^{23}$ In addition to the Mass in Tr.91, six Italian sources have both the text and the rhythmic divisions; a seventh source, $M C$, does not have the text but is otherwise clearly part of the Italian tradition; it has the rhythmic divisions and is linked with Esc and Pix by many additional shared readings. ${ }^{24}$

Most of the sources in this Italian group have been dated in the 1470s and $1480 \mathrm{~s}^{25}$ The earliest, $P a v$, dates from the $1460 \mathrm{~s}^{26}$ and, significantly, is one of the few sources which retains the imperfect time signature at the beginning of the

20 All are edited in Sylvia W. Kenney, Walter Frye: Collected Works, 3-8.

21 Heinrich Besseler, ed., Guillaume Dufay: Opera Omnia, 6 (Rome: American Institute of Musicology, 1964), Nos. 11, 15, 16.

22 Manfred Bukofzer, ed.,John Dunstable: Complete Works, Musica Britannica 8 (London: Royal Musical Association, 1953).

23 One such reading is in the discantus at measure 7, beat 3: the Italian group has two minims instead of a semibreve. Another is at the beginning of the B-section (m. 14): the Italian group has a semibreve and two minims in the discantus, and two semibreves in the tenor.

24 The most noteworthy of these is at the beginning in the contratenor: in the three sources named this voice begins on $\mathrm{F}$, a fifth below the usual starting note. Evidently this revision was intended to create a unity of tonality between the opening sonority and the sectional cadences.

25 Tentative datings for all the sources listed in Table 2 are given in the Census-Catalogue.

26 Nanie Bridgman in RISM B IV/5: 326. 
Table 2. Bedingham, "Fortune elas/Gentil madonna" (example 2): Sources

BerK Berlin. Staatliche Museen, Kupferstichkabinett, Ms. 78.C.28 (Ham. 451), ff. 18v-19 “F”. Census 1: 59; 4: 272 (BerlSM 78.C.28).

Cord Paris. Bibliothèque nationale, Rothschild Ms. 2973 (Cordiforme), ff. 3v-5 "Gentil madona". Census 3: 35; 4: 464 (ParisBNR 2973).

Esc San Lorenzo del Escorial. Real Monasterio, Ms. IV.a.24, ff. 117v-118 "Gentil madona." Census 1: 211; 4: 368 (EscSL IV.a.24).

5023 Munich. Bayerische Staatsbibliothek, Ms. Latinus monacensis 5023, ff. 8v-9v (discantus and tenor only) "Fortune / domine miserere". RISM B IV/3: 361. Census 2: 237; 4: 445 (MunBS Lat.5023).

MC Montecassino. Ms. 871, f. 62v "Fortuna las.” RISM B IV/5: 301. Census 2: 173; 4: 442 (MonteA 871).

Mel New Haven. Yale University Library, Ms. 91 (Mellon chansonnier), ff. 63v-65 "fortune elas / Gentil madona." Census 2: 248; 4: 450 (NHavY 91).

Pav Pavia. Biblioteca universitaria, Ms. Aldini 362, ff. 26v-27, "Gentil madona". RISM B IV/5: 326. Census 3: 42; 4: 465 (PavU 362).

Pix Paris. Bibliothèque nationale, fr. 15123 (Pixérécourt ms.), ff. 89v-90 "Gentil madonna". Census 3: 23; 4: 463 (ParisBNF 15123).

S-P Paris, Bibliothèque nationale, n.a.fr. 4379 (first section originally part of Seville, Colombina, Ms. 5.I.43), ff. 21 v-22 “Gentile madone.” Census 3: 29; 4: 463 (ParisBNN 4379).

Sched Munich. Bayerische Staatsbibliothek, Ms. Germanicus monacensis 810 (olim Cim 351a, Ms. 3232), ff. 48v-49 "fortune Jo. bodigham". Census 2: 236; 4: 445 (MunBS Germ. 810).

Spec Hradec Kralove, Krajske Muzeum, Ms. II.A.7 (Specialnik ms.), pp. 402, 404 405 "Festo isti". Census 1: 272; 4: 405 (HradKM 7).

Keyboard arrangement:

Bux Munich. Bayerische Staatsbibliothek, Ms. Cim. 352b (Buxheim Organ Book), f. 66v. Edited in Bertha Wallner, Das Buxheimer Orgelbuch, Das Erbe deutscher Musik 38 (Kassel: Bärenreiter, 1955): 162 (No. 124).

Tenor mass:

Tr.91 Trent. Castello del Buon Consiglio, Ms. 91, ff. 247v-256v (Nos. 1358-1362). RISM B IV/5: 514. Census 3: 228; 4: 479 (Trent C 91).

Editions:

Perkins, Leeman, and Howard Garey. The Mellon Chansonier (New Haven: Yale University Press, 1979), 1: 160-63.

Pope, Isabel, and Masakata Kanazawa. The Musical Manuscript Montecassino 871

(Oxford: Oxford University Press, 1978), 376-77.

References: See Table 1. 
second section. Spec, as mentioned, has neither the Italian text nor the rhythmic divisions; in this it resembles two other middle European sources, Sched and $B u x .^{27}$ All three share several additional readings, including one found in the tenor of example 2 at mm. 27-28. At this point in Italian sources the tenor reaches $\mathrm{g}$ twice in successive measures, ${ }^{28}$ a reading which can be seen in the editions of the piece listed in table 2. Spec, by supporting the alternative (and probably original) readings in Sched and Bux, confirms the value of these German sources, which are sometimes too quickly dismissed as "peripheral." Sched in particular is noteworthy because it is the earliest dateable source: Besseler has pointed out that the first two-thirds of the manuscript, including Bedingham's song, was copied by about 1462, when Schedel left the University of Leipzig, or at most a year later. ${ }^{29}$ Besseler also asserts that although his exemplars were occasionally corrupt, Schedel himself was a reliable copyist - a comforting thought, since, as noted earlier, his manuscript is the only source for the ascription to Bedingham.

The supplementary voices in Spec substantially alter the effect of Bedingham's original three-voice song. Bedingham's contratenor moves in the same range as the tenor, and the two parts cross freely; the alternative bassus part lies in a lower register and remains the bass of the ensemble throughout. Thus, the overall range has been noticeably deepened: at many points the bassus sounds an octave lower than the original contratenor. In passages where the contratenor was above the tenor, the bassus introduces a new harmonic foundation; in particular, it converts most of the Burgundian cadences to 5-1 or, in a few cases, to the deceptive 56 (mm. 23 and 31).

The other added voice, the triplum, extends the composite range upwards. The discantus reaches no higher than d' (several times) and e' (once); the triplum moves freely in this register and above, reaching a' once in each section. The high register and wide range of this part, its unusual rhythmic activity, and the decidedly "unvocal" octave leap at $\mathrm{m}$. 5 all suggest that the triplum was conceived instrumentally, even though it does imitate the discantus at one point (mm.7-8). For the most part, the triplum consists of a limited number of melodic figures used over and over: a scalewise descending fourth in dotted rhythm ( $\mathrm{mm}$. $3,14,17,36$ ); other scalar dotted rhythms (mm. 2, 4, 9, 33, etc.); and a distinctive cadential figure ending a third above the final (mm. 5, 12, 35, 40). This suggests that the part was originally improvised out of a repertory of stock figures.

That the triplum was conceived as an instrumental part should come as no

27 I have not been able to check the readings in 5023 .

28 Tenor: measure 27 , fourth note: $\operatorname{minim} f$; measure 28 : semibreve $g, \operatorname{minim} f$, etc.

29 Heinrich Besseler, "Schedel," in Die Musik in Geschichte und Gegenwart, ed. Friedrich Blume (Kassel: Bärenreiter, 1963), 9: 1609-12. 
particular surprise, since there is no lack of instrumental ensemble music in manuscripts roughly contemporaneous with Spec: examples include wideranging parts written on an eight-line staff, ${ }^{30}$ written-out basse danse music and embellished settings of German dance tunes,${ }^{31}$ and great quantities of music simply written down without any text. Even the disparity of melodic styles is not unprecedented: something similar can be found at the turn of the sixteenth century in chanson arrangements with added altus or second discantus parts which are faster-moving and wider-ranging than the voices they supplement. ${ }^{32}$ Spec simply contributes an additional example - a particularly striking one - to this extensive repertoire.

As to why the triplum stops for five bars in the middle of the B section, the following explanation can be offered: this is the point of greatest activity in the original song - the only passage where all the voices move continually in minims (eighth notes in transcription), and in this passage both discantus and tenor reach their highest pitch. The Spec redactor may have preferred not to obscure the natural climactic effect of the sequence-like rising lines in the discantus and tenor, or he may have simply felt that the passage could stand on its own without embellishment.

The Spec manuscript cannot be dated precisely, ${ }^{33}$ but by analogy with other sources containing similar repertoires ${ }^{34}$ one can suggest that the oldest layer dates from the 1470s or 1480s, and that the bulk of the manuscript was copied by about 1520. Blind-tooled into the binding is the date 1540 , which provides a terminal date. ${ }^{35}$ Bedingham's piece with its added parts (example 2) was copied into the oldest part of Spec, near works by Touront, Pullois, Morton, and Frye (the

30 TrentC 89, ff. 402v-403v (No. 761); see B. Disertori, "L'unica composizione sicuramente strumentale nei codici tridentini," Collectanea historicae musicae 2 (Florence: Olschki, 1957): 135.

31 Examples include the "Pfobenschwanz" settings in the Glogauer Liederbuch (BerlPS 40098), Nos. 22 and 208, edited in Heribert Ringmann, Das Glogauer Liederbuch 1, Das Erbe Deutscher Musik 4 (Kassel: Bärenreiter, 1936): 88-89.

32 See in particular the discussion of instrumental style in Sarah Fuller, "Additional Notes," Musica Disciplina 23 (1969): 86-99.

33 The date 1611 , found in a note of presentation on the inside of the front cover, has long since been accepted as irrelevant to the manuscript's contents, which are generally thought to be from the late fifteenth or early sixteenth centuries. See Cerny, Soupis, 41; Census 1: 272.

34 In terms of white-note concordances, the most nearly related manuscripts (and their dates, as given in the Census-Catalogue) are: BerlS 40021 (ca.1485-1500); MunBS 3154 (ca. 14661511); WarU 2016 (ca. 1500); MunBS Germ.810 (Sched: ca. 1460-1470); TrentC 89 (ca. 1460 1480); and BerlPS 40098 (ca. 1480). Spec's repertoire of black-note "peripheral polyphony" relates it to numerous Czech sources dating from the first half of the sixteenth century.

35 Cerny, Soupis, 41. 
famous "Ave Regina," with its added altus part); all of these were copied in the same hand and listed in the original register of the manuscript on pp. 606-8. The excerpt from Brumel's mass (example 1) is in a different hand and appears in a section of the manuscript which was added after the original compilation of the register, hence at a somewhat later time. ${ }^{36}$

This article has brought to light some new sources for example 1, and it has offered a new interpretation of example 2 along with a re-evaluation of its sources. The author's sub-text might be that scholars cannot afford to overlook any source, no matter how marginal. As in the case of Spec, the source may contain important new examples of a contemporary practice such as instrumental ornamentation, and even its versions of well-known works may prompt further consideration of the works and their sources. Thus every manuscript has its own contribution to make, and none can be dismissed out of hand.

\begin{abstract}
The Specialnik manuscript (HradKM II.A.7), from early sixteenth-century Bohemia, includes two well-known works with unique supplementary voices. One work, the final Agnus of Brumel's Missa Ut re mi fa sol la, includes an added bassus which deepens the composite range and animates the original without seriously disrupting it. An analysis of this movement shows why it was popular as an independent instrumental piece: it is clearly structured as statement and heightened reprise. The second work, Bedingham's "Fortune/Gentil madonna" contains a similar kind of bassus (as a substitute for the original contratenor) and also a triplum which exhibits characteristics of an idiomatic instrumental style. The Spec arrangement prompts a re-examination of the other sources and a demonstration that Bedingham's song originally called for a change from triple to duple mensuration in its B section.
\end{abstract}

36 It is not possible to be more precise about the date because the other works in this section of Spec (pp. 206-54) are all unica, and the only composer named is the otherwise unknown "Thomek." 